DOI https://doi.org/10.15589/znp2020.4(482).2

УДК 57.087

\title{
ANALYSIS OF THE EXPERIENCE OF USING THE QUALITIES OF MARINE MAMMALS IN THE CREATION OF ROBOTIC MARINE VEHICLES
}

\section{АНАЛІЗ ДОСВІДУ ВИКОРИСТАННЯ ЯКОСТЕЙ МОРСЬКИХ ССАВЦІВ ПІД ЧАС СТВОРЕННЯ РОБОТИЗОВАНИХ МОРСЬКИХ АПАРАТІВ}

\author{
Kateryna V. Marinicheva \\ k.marinicheva@ukr.net \\ ORCID 0000-0001-6462-3643 \\ Oksana N. Savinok \\ ORCID: 0000-0002-4095-7267 \\ savoksamit12@gmail.com \\ Tetiana A. Kobzar \\ ORCID: 0000-0002-6008-8505
}

\author{
К. В. Марінічева, \\ молодший науковий співробітник
}

О. М. Савінок,

канд. техн. наук, доцент

T. А. Кобзар,

науковий співробітник

\author{
Research Center of the Armed Forces of Ukraine "State Oceanarium" \\ of the Institute of Naval Forces of the National University “Odesa Maritime Academy", Odesa \\ Науково-дослідний центр Збройних Сил України "Державний океанаріум» \\ Інституту Військово-Морських Сил Начіонального університету «Одеська морська академія», м. Одеса
}

\begin{abstract}
The purpose of the article is to summarize and analyze the experience of studying the main properties of marine mammals, which have found and may find application in the future, in the creation of surface and underwater robotic vehicles and naval weapons.

Research methods are system-structural and didactic-analytical.

A review of modern developments of the leading technologically developed countries made it possible to conclude that there are robotic systems capable of conducting combat operations with a high degree of autonomy without human intervention. All developments are based on bionic elements.

The article presents an analysis of research in the field of biohydrodynamics. It was determined that the main objects of study of this scientific direction are hydro- and aerobionts. In their studies, scientists focused on the shape of the animal's body and its change during movement, the locomotor apparatus that creates traction and lifting force, bioenergetics, the interaction of the aquatic environment with the body of the animal. It is noted that, in contrast to technical objects, living organisms, flying or floating, mainly use flapping engines (wings, fins), the operating principle of which has not yet been fully studied. The research results formed the basis for the development of physical and mathematical models used in aircraft and shipbuilding.

The article presents the characteristics of some morphological properties of marine mammals and their practical application in the creation of naval weapons. Of particular relevance are the results of studies of the sonic echolocation system of dolphins, whales, their implementation in network-centric technologies, which make it possible to increase the efficiency and effectiveness of combat control and interaction of mobile fleet units with sea ones, forces and means. Analysis of promising robotic systems showed that the natural qualities of marine mammals were widely used in their creation.

Analysis of promising projects shows that in the near future the IRS with different goals will confidently take its place in the maritime (both surface and underwater) sphere of hostilities. At the same time, it can already be argued that the widespread use of natural qualities of marine mammals in the creation of robotic systems contributes to the creation of universal, economical and promising innovative models.
\end{abstract}

Key words: combat marine robotic systems; autonomous uninhabited underwater vehicles; morphological properties of marine mammals; waving engines of aquatic organisms; bionic forms; laminarization; underwater environment control; unmanned vehicles.

Анотація. Метою статті було узагальнення та аналіз досвіду досліджень основних властивостей морських ссавців, які знайшли та можуть знайти застосування в майбутньому, під час створення надводних і підводних роботизованих апаратів і морських озброєнь. 
Методи дослідження - системно-структурний і дидактично-аналітичний.

Огляд сучасних розробок провідних технологічно-розвинених країн дав змогу зробити висновок про наявність робототехнічних комплексів, які здатні з високим ступенем автономності вести бойові дії без участі людини. В основі всіх розробок $є$ елементи біоніки.

У статті наведено аналіз досліджень у сфері біогідродинаміки. Визначено, що основними об'єктами для вивчення цього наукового напряму стали гідро- і аеробіонти. У дослідженнях, основний акцент учені робили на формі тіла тварини та її змінах у процесі руху, руховому апараті, що створює тягу і підйомну силу, біоенергетиці, взаємодії водного середовища з тілом тварини. Зазначено, що, на відміну від технічних об'єктів, живі організми, що літають або плавають, використовують переважно махаючі рушії (крила, плавці), принцип дії яких ще досі не повністю вивчений. Результати досліджень стали основою під час розроблення фізичних і математичних моделей, які використовуються в авіа- і суднобудуванні.

У роботі наведено характеристики деяких морфологічних властивостей морських ссавців та їхнє практичне застосування під час проєктування морських озброєнь. Особливої актуальності набувають результати досліджень звукоехолокаційної системи дельфінів, китів під час їх впровадження в мережецентричні технології, які дають змогу підвищити оперативність і ефективність бойового управління та взаємодію мобільних з'єднань флоту із силами й засобами морського базування.

Аналіз перспективних проєктів показує, що в недалекому майбутньому морські роботизовані системи найрізноманітнішого призначення впевнено посядуть своє місце в морській (як надводній, так і підводній) сфері військових дій. Водночас уже нині можна констатувати, що широке застосування природних якостей морських ссавців під час створення робототехнічних комплексів сприяє створенню універсальних, економічних і перспективних інноваційних моделей.

Ключові слова: бойові морські роботизовані системи; автономні ненаселені підводні апарати; морфологічні властивості морських ссавців; махаючі рушії гідробіонтів; біонічні форми; ламінаризація контроль підводної обстановки, безпілотні апарати.

\section{ПОСТАНОВКА ЗАДАЧІ}

Стратегією Військово-Морських Сил Збройних Сил України (далі - ВМС ЗС України) 2035 року передбачається поетапне нарощування спроможностей військово-морського флоту (далі - ВМФ), включаючи генерацію сил, їх освіту і підготовку до морських та об'єднаних операцій. Головним завданням ВМС ЗС України є забезпечення підводної охорони та поінформованості в зоні морської відповідальності України.

3 урахуванням сучасних розробок та напрямків, максимальна ефективність поставленої задачі може бути досягнута за рахунок використання безпілотних підводних та надводних апаратів, утримання яких $\epsilon$ економічно вигідніше, ніж перебування в морі катерів, суден.

\section{АНАЛІЗ ОСТАННІХ ДОСЯГНЕНЬ І ПУБЛІКАЦІЙ}

Однією з сучасних концепцій ведення війни на морі $\epsilon$ концепція застосування морських роботизованих систем (далі - МРС). Безекіпажні (безпілотні) системи дозволяють більш ефективно виконувати бойові завдання, мінімізуючи при цьому людські втрати. У подальшій перспективі спектр бойових завдань МРС розшириться аж до повної заміни нероботизованих систем та людських ресурсів [1].

Збройні сили держав світу все більше інтегрують безпілотні системи різного призначення в свої арсенали. Для військово-морських сил розглядаються три категорії такого обладнання: ненаселені підводні апарати (далі - НПА) (Unmanned Underwater Vehicles,
UUV); ненаселені надводні апарати (далі - ННА), або судна (Unmanned Surface Vessels - USV) і безпілотні літальні апарати (далі - БЛА) (Unmanned Aerial Vehicles, UAV) [2].

Сучасні самохідні НПА - це окремий клас робототехнічних об'єктів 3 притаманними їм завданнями, особливостями технології, складом систем і функціональними властивостями. Попри всю різноманітність самохідних НПА (за цільовим призначенням, масогабаритними характеристиками, конструктивним виглядом, типом енергосилових установок і т.п.) загальновизнаної класифікації в цьому класі робототехніки ще не склалося. Тому в зарубіжних публікаціях, присвячених аналізу стану та прогнозу розвитку НПА, наводяться досить суперечливі факти і статистичні відомості. Огляд вітчизняних і зарубіжних публікацій в галузі підводної техніки дозволив сформулювати найбільш загальний і несуперечливий умовний розподіл самохідних НПА [2].

Усі самохідні НПА (UUV - Unmanned Underwater Vehicle) поділяють на два великих підкласи: неавтономні (прив'язні) НПА і автономні ненаселені підводні апарати (далі - АНПА).

Самохідні НПА можуть бути плаваючими в товщі води, самохідними донними або з комбінованим типом руху. До АНПА відносяться самохідні НПА 3 автономною системою енергозабезпечення та, як правило, бездротовим каналом телеуправління і зв'язку.

Треба зазначити, що розподіл НПА за ознакою автономності сформувався в процесі еволюції цього 
виду техніки, і під автономністю розуміється, перш за все, енергетична незалежність апарату від судна-носія.

Самохідні НПА вже сформувалися в досить представницький клас робототехнічних засобів, що налічує понад 500 різних проєктів (моделей). Провідні морські держави активно займаються створенням бойових морських роботизованих систем для власних військово-морських сил [1]. У розробці та виробництві самохідних НПА провідне місце займають США, Великобританія, Канада, Франція, Німеччина і Японія [3].

Нині технічно розвиненими країнами та перш за все США в інтересах ВМС активно ведуться роботи в галузі створення ненаселених платформ і ненаселених підводних апаратів. Водночас якщо у сфері створення повноцінних ненаселених платформ успіхи поки досить скромні, то у сфері створення ненаселених підводних апаратів (НПА) окреслилася низка проривних розробок. Однак стрімкий розвиток робототехніки та використання найсучасніших технологій не забезпечує вирішення, на теперішній час, деяких проблемних питань:

- створення двигунів, що дозволяють знизити енергозатрати та рівень шуму робототехнічних засобів;

- створення трансгенних біополімерів, що застосовуються при розробці ультралегких, надміцних, еластичних матеріалів з підвищеними характеристиками малопомітності для корпусів БПЛА та інших робототехнічних засобів;

- створення розвитку обчислювальних систем і систем зв'язку [4].

Для розв'язання вищевказаних проблемних питань у системі розвитку робототехніки провідними вченими світу вивчаються якості живих організмів, зокрема, морських ссавців. Це пояснюється усвідомленням факту, що до теперішнього часу всі біологічні системи перевершують за своїми можливостями характеристики більшості існуючих технічних засобів аналогічного призначення. Одним з основних напрямів досліджень науковцями є характер рушійних сил морських ссавців та механізм їх забезпечення за рахунок особливостей форми тіла. Окрім ламінаризованої форми тіла, у китоподібних і швидкісних риб існує ще ціла система природних застосувань, які забезпечують ефективне переміщення у водному середовищі. Гідродинамічна оптимізація покривів тварин дозволяє впливати на прикордонний шар середовища, робити його ламінарним, зменшити тертя. Ця особливість знайшла застосування в кораблебудуванні та робототехніці. Особливості функціонально-морфологічних властивостей і кінематики руху китоподібних стали прототипом при створенні сучасних трансгенних біополімерів для корпусів БПЛА та інших робототехнічних засобів. Важливе питання у розвитку робототехніки - створення систем зв'язку теж може бути вирішене із вивченням і використанням якостей звукоехолокаційної системи дельфінів.

\section{ВІДОКРЕМЛЕННЯ НЕ ВИРІШЕНИХ РАНІШЕ ЧАСТИН ЗАГАЛЬНОӤ ПРОБЛЕМИ}

В основі принципу дії всіх безпілотних апаратів лежать динамічні та кінематичні характеристики біологічних об'єктів. За останні два сторіччя проведений великий обсяг теоретичних досліджень в напрямку пошуку природних прототипів та закономірностей, які природа вдосконалювала упродовж мільйонів років. В процесі еволюції у китоподібних і швидкісних риб була створена ціла система природних застосувань, що дозволяють не тільки вижити у водному середовищі, а й ефективно переміщуватися, регулювати процеси дихання і теплообміну, харчуватися, спілкуватись і знаходити навігаційні орієнтири у водному середовищі. Деякі сучасні технічні засоби, в тому числі і безпілотні апарати: повітряні, наземні і морські вже спроєктовані, як прототипи живих організмів. Дослідники активно вивчають і застосовують як прототип морфологічні та фізіологічні якості морських ссавців в кораблебудуванні і в створенні роботизованих апаратів.

\section{МЕТА ДОСЛІДЖЕННЯ}

Враховуючи накопичений досвід провідних вчених у вивченні морських ссавців, метою статті було узагальнення та аналіз досліджень основних властивостей морських тварин, в тому числі і ссавців, при створенні роботизованих апаратів, які можуть знайти застосування як в надводному, так і в підводному положенні. Основні методи дослідження, які були використанні для проведення аналізу проблеми - системно-структурний та дидактично-аналітичний.

\section{ОСНОВНИЙ МАТЕРІАЛ}

3 далеких часів увагу дослідників природи і вчених привертали висока досконалість і виняткова пристосованість живих організмів до умов навколишнього середовища. Леонардо да Вінчі, М.В. Ломоносов, К.Е. Ціолковський, Н.С. Жуковський, В.В. Голубєв та інші намагалися осягнути глибоко заховані природою секрети «живих прототипів» і використати отримані знання в різних технічних пристроях [5]. Завдяки спільним зусиллям біологів, фізиків, математиків, інженерів в XX столітті сформувався новий напрям науки - біоніка. Сутність цієї науки зводиться до використання знань, отриманих в біології, для створення технічних об'єктів на нових фізичних принципах, запозичених у природи.

Великий обсяг досліджень у минулому сторіччі було проведено в біогідродинаміці [5]. Основними об'єктами для вивчення цього наукового напрямку стали гідро- і аеробіонти, тобто живі організми, які переміщаються в водному та повітряному середови- 


\section{СУДНОБУДУВАННЯ № 4- 2020}

щах. На відміну від технічних об'єктів, живі організми, що літають або плавають, використовують, переважно, махаючі рушії (крила, плавці), принцип дії яких ще досі не повністю вивчений. Предметом вивчення вчених і інженерів є форма тіла тварини і їі зміни в процесі руху, руховий апарат, що створює тягу і підйомну силу, біоенергетика, взаємодія водного середовища $з$ тілом тварини. В ході досліджень розробляються фізичні та математичні моделі, на основі яких проводиться комп'ютерний експеримент, створюються технічні експериментальні установки. Особливе значення біогідродинаміки полягає в тому, що результати досліджень використовуються в авіаі суднобудуванні.

Завдання сучасного науково-технологічного напрямку полягає у вивченні не тільки будови, морфологічних особливостей, але і функцій живих організмів, принципів дії їх рушіїв для використання отриманих відомостей при створенні нових механізмів. Так актуальними на теперішній час є самохідні моделі, принцип дії яких оснований на спрощених фізичних схемах природних аналогів. У монографіях Л.Ф. Козлова, С.В. Першина, А.К. Бродського, В.Л. Свидерського викладені результати теоретичних та експериментальних досліджень махаючих рушіїв аеро- і гідробіонтів. Відомі також теоретичні і експериментальні роботи іноземних вчених Т. Кармана, Д. Грея, Дж. Лайтхілла, Т. Ву, Дж. Прінгл, В. Нахтігалю [5].

Ахмедовим Т.Х., Бродским О.К., Галаніним I.Ф., Зелєєвим Р.М. були розроблені і виготовлені механічні гідромоделі з різними типами рушіїв. Характерними рисами яких $є$ корпуси кожної моделі, плавцеві стебла і плавці. Рухи моделей нагадують рухи їх природних аналогів - дельфінів, морських черепах, пінгвінів. Під час проєктування моделі завданням авторів було таке поєднання конструктивних елементів, за якого під час здійснення махових рухів крил з'явилася б можливість створення режиму «чистої» тяги. Крила моделі виготовлені жорсткими і роблять вільні обернено-обертальні рухи, обмежені верхніми жорсткими та нижніми підпружиненими упорами щодо осі, яка проходить у переднього краю крила. Однак водночас площина махових рухів нахилена. Вісь, на якій підвішене крило, вигнута. У підсумку, на початку махового руху крила дещо нахилені вперед, а в міру опускання вони відводяться назад. У перспективі, автори прогнозували, що ця модель може стати прототипом підводного апарату з махаючими крилами.

Подібно аеробіонтам, характерною рисою “конструктивних елементів” тіла гідробіонтів є їх гнучкість. Численними дослідженнями біологів встановлено, що форма тіла, іiі зовнішня і внутрішня структури знаходяться в залежності від швидкості руху морських тварин. Помічено, що у риб зі збільшенням швидкості їх плавання збільшується частота махових рухів плавця, з'являється потреба в більш міцному скелеті. А це досягається зменшенням числа хребців, збільшенням їх міцності і, відповідно, зменшенням гнучкості тіла риби [6]. Технічною мовою це явище означає зменшення числа ступенів свободи конструкції. Продовженням цієї ідеї стало створення моделей, що мають жорсткий корпус, плавцеві стебло і плавець [7].

Велику увагу дослідники приділяють ламінаризованій будові тіла морських ссавців. Результати гідробіонічних досліджень форми тіла гідробіонтів знайшли практичне використання при створенні технічних засобів руху в воді (підводні човни і апарати, торпеди, гідроакустичні апарати і ін.), а також в авіаціі [8].

Розглянемо застосування біонічних форм у створенні підводних апаратів. Під час проєктування АНПА використовують біонічні форми двох типів: плаваючого і повзаючого.

Форма повзаючого типу була прототипом у дослідників з Iрану (Iman Zare, Omid Zare, Shahid Chamran) при розробці біонічного мікроробота з вісьмома ногами, забезпеченого багатоступеневою свободою рухів. Науковці розробили модель для цільової реалізації у різноманітних програмах із вивчення міграції тварин, моніторингу океанських течій, глибинних вимірювань та військової і хімічної розвідок [9].

Біонічні форми найчастіше застосовують для автономних підводних мікроаппаратів (АПМА, micro AUV), до яких відносяться апарати масою менше 20 кг. Дана категорія становить 20-25\% від загального числа відомих проєктів АНПА. Велика частина (50-60\%) моделей АПМА створюється 3 використанням біонічних принципів і носить експериментальний характер. Типові технічні характеристики цієї категорії апаратів: дальність плавання не більше 1-2 морських миль, гранична робоча глибина менше 150 м; швидкість ходу - 1,5-2 вузли [10].

Початковим прикладом використання біонічних форм також може бути створення у 1987 р в Великобританії океанографічною лабораторією Proudman при співробітництві вчених Ради по вивченню навколишнього середовища NERC (Natural Environment Research Council) за програмою Autosub (Autonomous Unmanned Submersible) двох АНПА, які відкрили великі можливості для проведення досліджень в області навігації, рибальства, експлуатації підводних родовищ, прогнозування погоди. Один 3 них, AHПА DOLPHIN (Deep Ocean Long Path Hydrographic Instrument), представлений на рисунку 1, призначений для вимірювань в товщі води, має виражену форму тіла дельфіна.

Апарат може бути використаний для збору інформації на маршруті в режимі програмного управління. Він занурюється і рухається поблизу дна, спливаючи через кожні кілька десятків кілометрів, щоб передати 
на системи GPS інформацію для подальшої ретрансляції іiі на наземні станції і прийому нової програми дій. Основною проблемою при створенні АНПА DOLPHIN було оснащення його компактним джерелом електроенергії з високими питомими характеристиками. До інших проблем, які треба було вирішити при створенні AHПА DOLPHIN, відносилися: вибір матеріалу конструкції і форми корпусу, що забезпечує низький гідродинамічний опір, забезпечення супутниковою телеметрією і навігацією, а також впровадження в систему управління елементів штучного інтелекту [11].

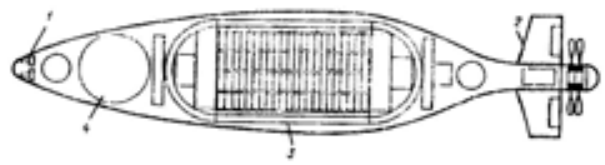

Рис. 1. Загальний вигляд моделі AHПA DOLPHIN [11]: 1 - антени системи Argos и GPS; 2 - блок управління рулями; 3 - баластна цистерна; 4 - джерела енергії, система управління і корисне навантаження

Прикладом впровадження характерних особливостей руху морських тварин, можна вважати розроблений китайськими вченими (Rui Ding, Junzhi Yu, Qinghai Yang, Min Tan, Jianwei Zhang) робототехнічний прототип, який дозволяє поєднати два різних режими плавання - рибоподібний та дельфіноподібний. Дослідники звернули увагу, що дорзовентральна локомоція дельфіна демонструє більш високу продуктивність у гідродинаміці плавання, але немає доказів щодо того, що плавання дельфінів передує плаванню риб за деякими показниками, такими, як споживання енергії, маневреність, швидкість. Дослідники побудували біоміметичного амфібійного робота, який містить у компактному вигляді переваги як риб, так і дельфінів. Цей робототехнічний прототип дозволить суттєво підвищити техніко-економічні характеристики та відкриває безліч перспектив у розвитку робототехніки [12].

За останні два-три десятиліття в різних країнах, що займають провідне положення в області морських технологій, було створено значну кількість НПА військового призначення. За цей період НПА не тільки продемонстрували свою ефективність при виконанні розвідувальних, протимінних і оглядово-пошукових робіт, а й відкрили ряд нових важливих застосувань.

Досягнення в науці та поява нових технологій безперервно розширюють сферу застосування НПА, і за останні 5-10 років кількість розробок автономних НПА зросла більш ніж 2 рази. [4].

Біонічна, ламінаризована форма корпусу надана конструкторами більшості сучасних НПА. Для порівняння розглянемо сучасні ненаселені підводні апарати виробництва "ATLAS Elektronik", які за своїми можливостями та будовою $є$ типовими для
НПА. “Типову” картину останніх досягнень в секторі ненаселених підводних апаратів передають прикладні системи виробництва компанії “ATLAS Elektronik GmbH" (Бремен, Німеччина): "Морська лисиця" (SeaFox), "Морський кіт" (SeaCat) i "Морська видра" (SeaOtter), НПА “Клавесин-2P” виробництва ЦКБ “Рубін”, Росія [13].

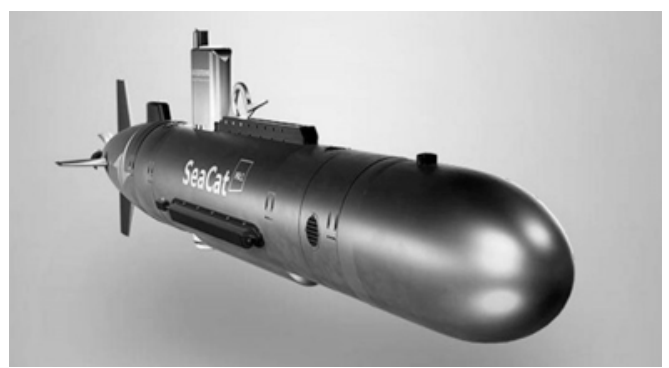

Рис. 2. НПА “SeaCat”[13]

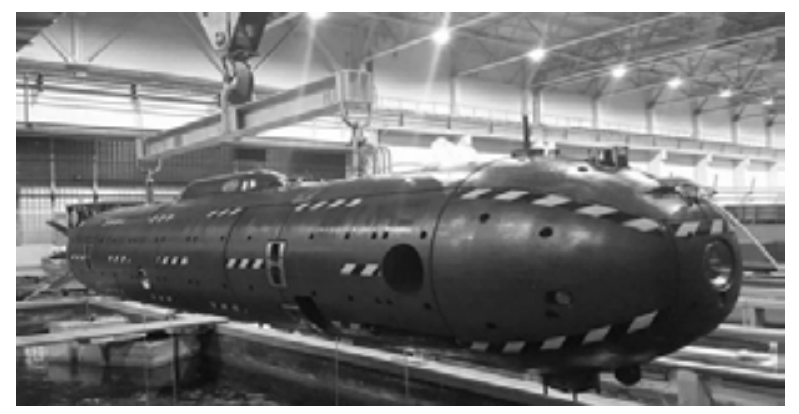

Рис. 3. НПА “Клавесин-2Р” виробництва ЦКБ “Рубін” Росія [13]

Ці ненаселені підводні системи призначені для виконання основних завдань: розвідка і знищення мін; збір даних про морське дно, стан води і течії; прихована розвідка і спостереження (наприклад, до висадки морського десанту або підтримки спеціальних сил); забезпечення безпеки своїх портів і суден [13].

Цікавою $є$ розробка напівавтономного підводного ненаселеного апарату, який має не тільки дельфіноподібну форму, а і заснований на біонічних принципах руху - проєкти GhostSwimmer i RoboTuna, Bluefin-21, Bluefin Robotics (General Dynamics). Невеликих підводних роботів Sand Sharks. BioSwimmer (BILIS), Boston Engineering, може запускати США [14].

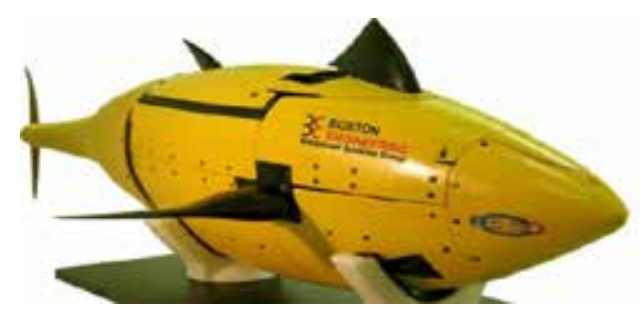

Рис. 4. Підводний військовий безпілотник "Блакитний тунець", "Bluefin-21 RoboTuna" (довжина - 4,9 м) [14] 
Найбільший автономний підводний робот із сімейства продуктів AUV виробництва французької компанії ЕCA (рис. 5), також має виражену біонічну форму і призначений для протидії мінуванням, здатний до виявлення, класифікації та локалізації мін.

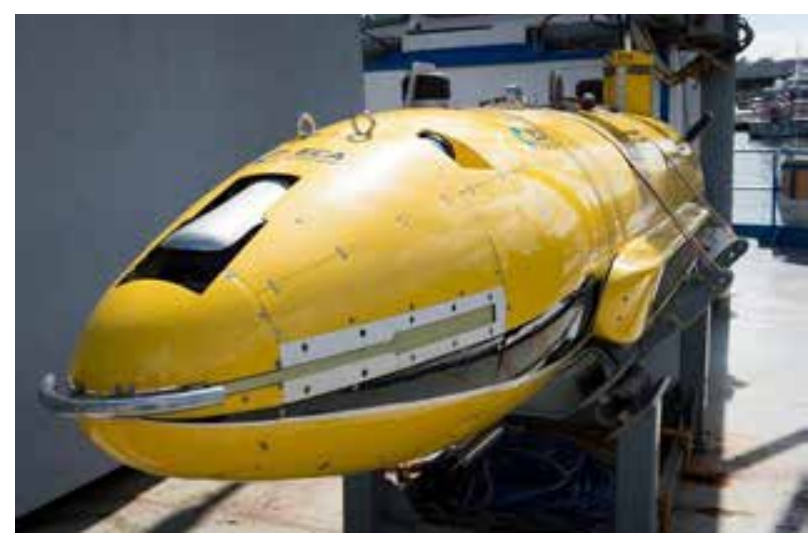

Рис. 5. НПА А27-M, ЕСА Group, Франція [14]

Термін автономної роботи - більше 35 годин. Робот оснащений сонаром 3 керованою апаратурою і системою підводного запуску і прийому на борт (LARS), що дозволяє використовувати систему в самих різних умовах на поверхні. Роботом управляє оновлене ПО UMIS, яке відповідає за рух UAV, збір і переробку даних [14].

Приклад надвеликого підводного дрону - "Orca", Boeing, США. Безпілотна субмарина класу XL UUV, “Orca", тобто (косатка), своїми параметрами повторює форми великого морського ссавця. Ламінаризована форма надає бюджетні переваги (в порівнянні 3 ненаселеними підводними човнами). “Orca” здатна, в теорії, займатися виконанням різних місій - від розвідки до поразки кораблів противника. Модульна конструкція дозволяє використовувати різне корисне навантаження, зокрема - може нести на борту сонар, легку торпеду MK. 46, а за необхідністю - важку Mk. 48, або навіть комплект протикорабельних ракет [14].

Ламінаризована форма тіла - це лише одне з пристосувань гідробіонтів до існування у водному середовищі. У китоподібних і швидкісних риб існує ціла система природних характеристик, які забезпечують ефективне переміщення у водному середовищі та цим привертають увагу дослідників. Концепцію нерозривного хвилеподібного руху морських риб і дельфінів взято за основу групою вчених польської Морської академії (Piotr Szymak, Marcin Morawski, and Marcin Malec) під час проєктування моделі біонічного підводного апарата - роботизованої риби під назвою Cyber Fish. Авторами була реалізована розроблена математична модель апарата. Кожна ділянка хвоста роботизованої риби коливається відповідно до синусоїди з регульованою амплітудою та частотою. Поворот риби-робота реалізується двома способами.
Один із них - шляхом зміни точки коливання кожної секції хвоста, що забезпечило здатність роботу обертатися навколо своєї вертикальної осі. Другий - це зміна точки нейтрального коливання першого перерізу, таким чином хвіст коливається уздовж осі, нахиленої до головної осі симетрії робота. Отже, Cyber Fish пливе по дузі, радіус якої залежить від нової точки нейтрального коливання першого перерізу. Експериментальні дослідження дозволили авторам розробки перевірити запропоновану математичну модель підводного транспортного засобу з хвилеподібним рушієм і переконатися в її дієвості [15].

Крім розробки НПА ведуться роботи в області створення надводних ненаселених апаратів. 3 представлених нижче моделей можна побачити, що при будуванні ННА активно застосовується дельфіноподібна, або рибоподібна форма корпусів. Так, наприклад, в Ізраїлі ведуться випробування відразу двох видів ненаселених плавальних апаратів. Один з них - бойовий катер “Протектор” розробки Рафаель, на який інженери встановили всю необхідну апаратуру для виявлення морських цілей. Катер створений на базі десантного катера, здатного нести більше 1 т вантажу і який призначений для використання ізраїльськими морськими командос [16].

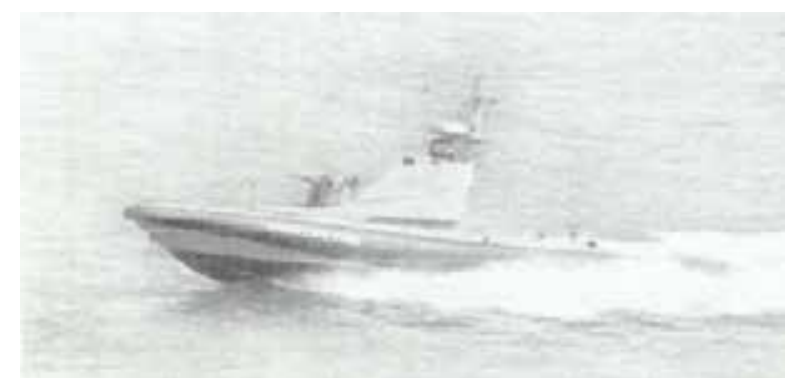

Pис. 6. БЕК з корпусом типу"V-Hull" Protector (Rafael Advanced Defense Systems Ltd., Ізраїль) [16]

11-метровий глісуючий БЕК класу Pieei, рис. 6. ННА забезпечує або помірну швидкість і невеликий запас ходу під час буксирування апаратури для пошуку мін, або високу швидкість та значний запас ходу під час виконання місій з протичовнової боротьби, надводних військових операцій або ведення радіоелектронної боротьби [16].

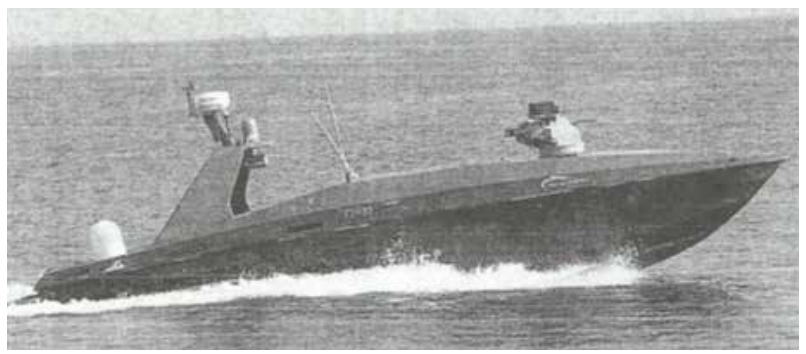

Рис. 7. Silver Marlin (Elbit Systems, Ізраїль) 
БЕК Silver Marlin (рис. 7), який навіть отримав назву за своїм прототипом - рибою марлін, розроблений компанією Elbit Systems (Ізраїль), входить до классу Fleet, здатний в автономному режимі патрулювати територію радіусом до 500 км. Призначення Silver Marlin може бути дуже різним - це розвідка, спостереження i рекогносцировка, охорона транспортних суден від терористичної і піратської загрози, виявлення і ліквідація морських мін, пошуковорятувальні операції [16].

Вивчення біонічних принципів дозволило дослідникам визначити особливості функціонально-морфологічних властивостей і кінематики руху китоподібних, можливі способи ламінаризації прикордонного шару у гідробіонтів:

- гасіння турбулентної пульсації в прикордонному шарі за рахунок пружнодемпфіруючих властивостей шкірного покриву гідробіонтів;

- виділення в прикордонний шар гідробіонтів біологічного слизу;

- нестаціонарний характер руху гідробіонтів [17].

Саме морфологія покривів морських тварин дозволяє впливати на прикордонний шар, робити його ламінарним, зменшувати тертя. Ця природна особливість знайшла своє застосування в робототехніці. Так фірмою Westinghouse Electric Corp. (США) ведуться дослідження зі збільшення дальності ходу АНПА за рахунок ламінаризації прикордонного шару води у корпуса апарату для зменшення гідродинамічного опору його руху. Зокрема, конструкторами фірми досліджується можливість введення в пристінну область турбулентного потоку рідини добавок високомолекулярних сполук. Опір тертя навіть при введенні незначних концентрацій полімерних розчинів, наприклад, поліоксилу, зменшується на $80 \%$ - для досягнення максимального ефекту зниження турбулентного тертя досить 0,01-0,02\% полімеру в розчині.

В літературі висловлюються певні думки щодо перспективи використання штучних пружнодемпфіруючих покриттів для підводної частини корпусів суден, посилаючись на дослідження принципів локомоції морських ссавців. Швидкісні ссавці здійснюють активне управління прикордонним шаром. Основа такої регуляції - зміна демпферних властивостей різних ділянок шкіри тварини, що дозволяє гасити турбуляцію і різко знизити опір. Подібний стан покривів - одна 3 провідних адаптацій до швидкісного переміщення представників групи. Ще в 60-і роки моделювання 3 демпфірувальними гумовими покриттями, дозволило зробити висновок, що покриви дельфіна знижують опір в 10 разів і дозволяють збільшити швидкість моделі більш ніж на 50\% при однакових енерговитратах [18]. Зміна пружності шкіри забезпечується здатністю до локального управління тиском крові в судинах окремих елементів покривів. У риб розвиток подібної регуляції неможливий із-за низького тиску крові і рівня розвитку сенсорної системи. Вважається, що практичній реалізації ідеї, запропонованої М. Крамером, перешкодила недостатня міцність можливих покриттів, які, що особливо важливо для швидкохідних судів, не мали, на той час, достатню довговічність і стабільні механічні характеристики. Крім того, незрозумілим був вплив обростання покриття на його ефективність. Однак, ряд сучасних полімерних композитних матеріалів цілком впораються із даними проблемами. Тому, вважається практично можливим використання цих покриттів не лише на торпедах, катерах, HПА і НHА, а також на виступаючих частинах підводних човнів, наприклад обтічниках гідролокаторів, 3 метою зменшення їх опору i, головним чином, для зменшення гідродинамічних шумів, поліпшення їх акустичних характеристик [19].

Окрім морфологічних, гідродинамічних властивостей морських ссавців, представляє інтерес використання можливостей їх звукоехолокаційної системи для розвитку робототехніки - створення обчислювальних систем і систем зв'язку.

Особливої актуальності набувають результати досліджень звукоехолокаційної системи дельфінів, китів при їх впровадженні в мережецентричні технології, які дозволяють підвищити оперативність і ефективність бойового управління та взаємодію мобільних з'єднань флоту із силами і засобами морського базування. Невід'ємною складовою таких технологій $\epsilon$ робототехнічні комплекси. Саме на них покладається питання із забезпечення зв'язку і підтримки навігаційних мереж [4].

В процесі еволюції у дельфінів сформувалося кілька одночасно працюючих в звуковому каналі систем: навігації, ехолокації і комунікації. Сигнали вони випромінюють за допомогою спеціальних органів, що відіграють роль передавальних антен, а отримують інформацію - відбиті власні імпульси на відповідні приймачі. Послідовності “випромінювання-прийом” в їх навігаційному і ехолокаційному апараті мають власну синхронізацію, а комунікативна система не вимагає тимчасового узгодження. Ехолокаційні сигнали кодуються. Це дає можливість відрізнити відбитий від цілі звук від власних імпульсів, у кожної особини є свій декодер [20; 21]. При вивченні ехолокаційної системи дельфіна виявлено, що він випромінює сигнали і сприймає їх у величезній смузі частот - від 20 до 200000 Гц (для порівняння: можливості людського слуху 20-20000 Гц). Ще в середині 70-х років $\mathrm{XX}$ ст. було розроблено апаратуру, що записує сигнали ссавців без спотворень. Однак, розроблена техніка прийому і передачі інформації, побудована на вузькосмугових сигналах, для вирішення такого складного завдання виявилася непридатною. Порівняння сигналів, сформованих за допомогою технічних систем, з їх аналогами у дельфінів показує, що біологічні тех- 


\section{СУДНОБУДУВАННЯ № 4-2020}

нології перевершують інженерні [22; 23]. Встановлено, що для дельфінів порогова інтенсивність звуку менше, ніж 10-13 ват на квадратний метр. Акустична система дельфіна, як і вушна раковина людини, збирає звуки не 3 цілого квадратного метра, а 3 площі, приблизно в 1000 разів менше, дельфін здатний розчути звук, якщо його вухо отримує звукову потужність менше ніж 10-16 ват. Тварини можуть окремо чути звукові частоти, що розрізняються лише на 3-4\%. Частотний аналіз слуху дельфінів в три рази чутливіший, ніж у людини і в 10 разів ширший. 50-70 пульсацій в секунду - межа розрізнення для слуху людини і для більшості тварин. Дельфін чує звукові вібрації 3 частотою 1500 в секунду і здатний вловити навіть пульсації з частотою близько 2000 в секунду. Саме тому, з 2002 р управління військово-морських досліджень, підрозділ космічних і морських озброєнь, комісія управління перспективних військових науково-дослідних і дослідно-конструкторських робіт Міністерства оборони США фінансують проєкти систем пошуку і класифікації замулених донних мін на основі біосонара. Здійснюються розробки автономних міні систем типу “робот-дельфін” і пристроїв на базі нових технологій з антенами, які використовують “дельфіноподібні” сигнали [24].

Вивчення навігаційних можливостей морських ссавців надихнуло вчених (Tomasz Praczyk) провести дослідження використання нейро-еволюційних методів для налаштування одометричної навігаційної системи (ONS) малих біоміметичних автономних підводних транспортних засобів (BAUV), що є перспективним напрямком у розвитку зв'язку і управління НПА. Система (ONS), яка використовується багатьма роботами для орієнтації в навколишньому середовищі, має інтегроване програмне забезпечення. На низькому рівні відбувається керування швидкістю, напрямком руху, а також глибиною занурення. Крім наведених вище параметрів, регульованими можуть бути швидкість обертання двигуна, положення маніпулятора, рух штучного плавця. Автори зробили висновок, що найвищий рівень програмного забезпечення 3 використанням нейро-еволюційних методів налаштування одометричної навігаційної системи
(ONS) дозволяє досягати цілей високого рівня, визначених людиною-оператором [25].

Дослідження спеціалістами Науково-дослідного центру Збройних сил України “Державний океанаріум” фізіологічних особливостей дельфінів започаткувало напрямок науково-дослідних робіт з розробки звукопідводного зв'язку, основаного на біонічних принципах. Науковці з'ясували, що акустичний зв'язок дельфінів вирішує проблеми боротьби з багатопроменевою інтерференцією звукових хвиль, стійкості до доплерівських зсувів, адаптивного налаштування сигналів на можливості каналу зв'язку [22]. Розроблена система цифрового звукопідводного зв'язку на біонічних принципах відрізняється зміною несучого сигналу постійної частоти на послідовність частотно-модульованих сигналів 3 високими частотними градієнтами, а також наявністю опорного ЧМ-сигналу для розрахунку доплерівських руйнувань в каналі в режимі реального часу. Експериментальні дослідження і проведені випробування системи, що реалізує інноваційний біонічний принцип підводного зв'язку, в природних умовах на зовнішньому рейді (глибина до 50 м) засвідчили впевнений багатокористувацький зв'язок в умовах швидкого руху і сильної ревеберації [22; 23].

\section{ВИСНОВКИ}

Проведений в статті аналіз показав, що провідні технологічно розвинені країни (в тому числі США, Росія, Великобританія, Франція, Китай, Ізраїль, Південна Корея), використовують при розробці робототехнічних пристроїв фізіологічні та морфологічні якості морських ссавців. Інноваційні робототехнічні системи, здатні 3 високим ступенем автономності вести бойові дії без участі людини. Аналіз перспективних проєктів показує, що в недалекому майбутньому МРС, найрізноманітнішого призначення, впевнено посядуть своє місце в морській (як надводній, так і підводній) сфері військових дій. Водночас уже зараз можна констатувати, що широке застосування природних якостей морських ссавців під час створення робототехнічних комплексів сприяє створенню універсальних, економічних і перспективних інноваційних моделей.

\section{REFERENCES}

[1] Yakimyak S.V. Combat marine robotic systems: problems and prospects for the national fleet. Innovations in shipbuilding and ocean engineering: materials of the VI international scientific and technical. conf. NUOU Mykolayiv, 24-27.09.2015 $508 \mathrm{~s}$.

[2] Arkhipov O. Self-propelled autonomous uninhabited submarines (SANPA) Underwater equipment and technology: materials of the VI All-Ukrainian scientific and technical conference with international participation: at 2 p.m. Mykolaiv: NUS, December 15-16, 2016. - Part 1. P. 3-8.

[3] Katenin V., Katenin A. Mine threat and navigation and hydrographic support of mine action. (GNINGS of the Ministry of Defense of the Russian Federation) "Defense order". 2007. № 15 June URL: http://www.ozakaz.ru/index.php/ articles/n-15-06-2007 (access date: 21.10.2019).

[4] Makarenko S.I. Robotic military complexes - the current state and prospects. According to the magazine "Control, Communication and Security Systems”. № 2. 2016 Systems of Control, Communication an d Security sccs.intelgr.com.

[5] Devices with swinging propellers and their natural analogues: a monograph / T. Kh. Akhmedov, A.K. Brodsky, I.F. Galanin, R.M. Zeleev. Moscow: Infra-Engineering, 2018. 360 p. 
[6] The theory of swimming of fish and dolphins: E.V. Romanenko Moscow: Science. 1986. 148 p.

[7] Hydrodynamics of fish and dolphins: E.V. Romanenko KMK. 2001. 412 p. (Project № 930421415).

[8] Hydrobionics in shipbuilding: a textbook / N.B. Slizhevsky. Nikolaev: UMMTU, 2002. 112 p.

[9] A Bionic Underwater Micro-robot with Eight Legs Using ICPF Actuators. Iman Zare, Omid Zare, Shahid Chamran. Conference Paper December 2015 URL: https://www.researchgate.net/publication/309384757)

[10] Uninhabited submarines: the state and general trends. Bocharov L., IPI RAEN Electronics: science, technology, business 7/2009.

[11] Golod O.S., Gonchar A.I., Shlychek L.I. Prospects and concepts for the development of autonomous uninhabited submarines. Hydroacoustic magazine. 2007 № 4.

[12] Dolphin-like Swimming Modeling for a Biomimetic Amphibious Robot * Rui Ding, Junzhi Yu, Qinghai Yang, Min Tan * Jianwei Zhang ** Proceedings of the 18th World Congress The International Federation of Automatic Control Milano (Italy) August 28 - September 2, 2011.

[13] Uninhabited submarines for military purposes According to the materials of the magazine "MarineForum" URL: https://invoen.ru/vvt/neobitaemye-podvodnye-apparaty/(date of application: 02.11.2019).

[14] Catalog of underwater military robotic vehicles. URL: http://robotrends.ru/robopedia/podvodnye-voennye-robotizirovannyeapparaty (access date: 15.01.2020).

[15] Conception of Research on Bionic Underwater Vehicle with Undulating Propulsion Piotr Szymak1, a, Marcin Morawski2, b and Marcin Malec3, c 1. Solid State Phenomena Vol. 180 (2012) pp 160-16. 2012. Trans Tech Publications, Switzerland doi URL: 10.4028 / www.scientific.net / SSP.180.160.

[16] Saustian J. Analysis and review of the main architectural and design features of unmanned surface boats for accurate collection and classification of statistics. Bulletin of Odessa National Maritime University. 2017. № 3 (52). P. 132-141.

[17] The theory of swimming of fish and dolphins: E.V. Romanenko Moscow: Science. 1986. 148 p.

[18] Kramer M.O. The mystery of dolphins // New Sci. 1960. Vip. 7. № 181. S. 1118-1120.

[19] Kravtsov V.I. Evaluation of the effectiveness of polymer composite materials as structural materials for the extremities of the hulls of underwater equipment. Collection of scientific works of NUS. Ser. Shipbuilding. 2013. № 4

[20] Rimskaya-Korsakova L.K., Dubrovsky NA Strategy of echolocation target recognition in dolphins by auditory peripheral coding, Acoustic Journal, Volume 52, № 4, 2006, p. 243-249.

[21] Finneran, J.J., and Houser, D.S. (2007). "Bottlenose dolphin (Tursiops truncatus) steady-stat e evoked responses to multiple simultaneous sinusoidal amplitude modulated tones," J. Acoust. Soc. Am.

[22] Kulagin V.V. Research Center of the Armed Forces of Ukraine "State Oceanarium", Sevastopol, 2011. 273 p.

[23] Kulagin V.V., B.A. Zhuryd Theory of Marine Biotechnical Systems, Sevastopol, 2010. 330 p.

[24] Au, W. W. L., and Nachtigall, P. E. Artificial neural network modeling of dolphin echolocation, in Sensory Systems of Aquatic Mammals, edited by R. A. Kastelein, J. A. Thomas, and P. E. Nachtigall (De Spil, Woerden, The Netherlands), 1995, p. $183-199$.

[25] Using Neuro-Evolutionary Techniquesto Tune Odometric Navigational Systemof Small Biomimetic Autonomous Underwater Vehicle-Preliminary Report Tomasz Praczyk1. Received:24 August 2018/ Journal of Intelligent \& Robotic Systems URL: https://doi.org/10.1007/s10846-020-01191-3).

\section{СПИСОК ВИКОРИСТАНОЇ ЛІТЕРАТУРИ}

[1] Яким'як С.В. Бойові морські роботизовані системи: проблеми та перспективи створення для національного флоту. Інновації в суднобудуванні та океанотехніці : матеріали VI міжнародної наук.-техн. конф. НУОУ м. Миколаїв, 24-27.09.2015 p. 508 c.

[2] Архипов О. Самохідні автономні незаселені підводні апарати (САНПА). Підводна техніка і технологія: матеріали VI Всеукраїнської науково-технічної конференції з міжнародною участю: в 2 ч. Миколаїв: НУК, 15-16 грудня 2016. Ч. 1. C. 3-8.

[3] Катенин В., Катенин А. Минная угроза и навигационно-гидрографическое обеспечение противоминных действий. (ГНИНГИ МО РФ) “Оборонный заказ”. 2007. №15 июнь URL: http://www.ozakaz.ru/index.php/articles/n-15-06-2007 (дата звернення: 21.10.2019).

[4] Макаренко С.И. Робототехнические комплексы военного назначения - современное состояние и перспективы развития. По материалам журнала “Системы управления, связи и безопасности”. № 2. 2016 Systems of Control, Communication an d Security sccs.intelgr.com.

[5] Аппараты с машущими движителями и их природные аналоги : монография / Т.Х. Ахмедов, А.К. Бродский, И.Ф. Галанин, Р.М. Зелеев. Москва : Инфра-Инженерия, 2018. 360 с.

[6] Теория плавания рыб и дельфинов : Е.В. Романенко Москва : Наука. 1986. 148 с.

[7] Гидродинамика рыб и дельфинов : Е.В. Романенко КМК. 2001. 412 с. (Проєкт № 930421415).

[8] Гидробионика в судостроении:учебное пособие/ Н.Б. Слижевский. Николаев : УГМТУ, 2002. 112 с.

[9] A Bionic Underwater Micro-robot with Eight Legs Using ICPF Actuators. Iman Zare, Omid Zare, Shahid Chamran. Conference Paper December 2015 URL: https://www.researchgate.net/publication/309384757) 
[10] Необитаемые подводные аппараты: состояние и общие тендеции развития. Бочаров Л., ИПИ РАЕН Электроника: наука, технология, бизнес 7/2009.

[11] Голод О.С., Гончар А.И., Шлычек Л.И. Перспективы и концепции разработки автономных необитаемых подводных аппаратов. Гидроакустический журнал. 2007 № 4.

[12] Dolphin-like Swimming Modeling for a Biomimetic Amphibious Robot $\star$ Rui Ding, Junzhi Yu, Qinghai Yang, Min Tan * Jianwei Zhang ** Proceedings of the 18th World Congress The International Federation of Automatic Control Milano (Italy) August 28 - September 2, 2011.

[13] Необитаемые подводные аппараты военного назначения. По материалам журнала "MarineForum" URL: https://invoen.ru/vvt/neobitaemye-podvodnye-apparaty/(дата звернення: 02.11.2019).

[14] Каталог подводных военных роботизированных аппаратов. URL: http://robotrends.ru/robopedia/podvodnye-voennyerobotizirovannye-apparaty (дата звернення: 15.01.2020).

[15] Conception of Research on Bionic Underwater Vehicle with Undulating Propulsion Piotr Szymak1, a, Marcin Morawski2, b and Marcin Malec3, c 1. Solid State Phenomena. Vol. 180 (2012), pp. 160-16. 2012. Trans Tech Publications, Switzerland doi URL:10.4028/www.scientific.net/SSP.180.160

[16] Саустіян Я. Аналіз та огляд основних архітектурно-конструктивних особливостей безекіпажних надводних катерів для точного збору та класифікації статистичних даних. Вісник Одеського національного морського університету. 2017. № 3(52). С. 132-141.

[17] Теория плавания рыб и дельфинов : Е.В. Романенко Москва : Наука. 1986. 148 с.

[18] Kramer M.O. The dolphins’ secret // New Sci. 1960. Vol. 7. № 181. P. 1118-1120.

[19] Кравцов В.И. Оценка эффективности полимерных композиционных материалов как конструкционных материалов для оконечностей корпусов подводной техники. Збірник наукових праць НУК. Сер. Кораблебудування. 2013. № 4.

[20] Римская-Корсакова Л.К., Дубровский Н.А. Стратегия эхолокационного распознавания целей у дельфинов слуховым периферическим кодированием, Акустический журнал, том 52, № 4, 2006, с. 243-249.

[21] Finneran, J.J., and Houser, D.S. (2007). "Bottlenose dolphin (Tursiops truncatus) steady-stat e evoked responses to multiple simultaneous sinusoidal amplitude modulated tones," J. Acoust. Soc. Am.

[22] Кулагін В.В. Науково-дослідний центр Збройних Сил України “Державний океанаріум”, Севастополь, 2011. 273 с.

[23] Кулагин В.В., Б.А. Журид Теория морских биотехнических систем, Севастополь, 2010. 330 с.

[24] Au, W. W. L., and Nachtigall, P.E. Artificial neural network modeling of dolphin echolocation, in Sensory Systems of Aquatic Mammals, edited by R.A. Kastelein, J.A. Thomas, and P.E. Nachtigall (De Spil, Woerden, The Netherlands), 1995, p. $183-199$.

[25] Using Neuro-Evolutionary Techniquesto Tune Odometric Navigational Systemof Small Biomimetic Autonomous Underwater Vehicle-Preliminary Report Tomasz Praczyk1. Received:24 August 2018/ Journal of Intelligent \& Robotic Systems URL: https://doi.org/10.1007/s10846-020-01191-3).

(C) К. В. Марінічева, О. М. Савінок, Т. А. Кобзар Дата надходження статті до редакції: 07.12.2020 Дата затвердження статті до друку: 18.12.2020 